Article

\title{
Greatly Enhanced Photovoltaic Performance of Crystalline Silicon Solar Cells via Metal Oxide
}

\author{
Lingling Zhou ${ }^{1}$, Lufei Xiao ${ }^{1}$, Hai Yang ${ }^{2}$, Jie Liu ${ }^{2, *(1)}$ and Xibin Yu ${ }^{2, *}$ \\ 1 Department of Food and Environmental Engineering, Chuzhou Vocational and Technical College, \\ Chuzhou 239000, China; zhoulingling2018@gmail.com (L.Z.); tangshiyong001@gmail.com (L.X.) \\ 2 The Education Ministry Key Laboratory of Resource Chemistry and Shanghai Key Laboratory of Rare Earth \\ Functional Materials, Department of Chemistry, Shanghai Normal University, Shanghai 200234, China; \\ benjaejong@gmail.com \\ * Correspondence: liujie@shnu.edu.cn (J.L.); xibinyu@shnu.edu.cn (X.Y.); Tel.: +86-21-64324528 (J.L. \& X.Y.)
}

Received: 13 June 2018; Accepted: 2 July 2018; Published: 7 July 2018

Abstract: Band-gap alignment engineering has now been extensively studied due to its high potential for application. Here we demonstrate a simple route to synthesize two metal oxide layers and align them together according to their bandgaps on the surface of crystalline silicon (c-Si) solar cells. The metal oxide layers not only extend absorption spectrum to generate extra carriers but also more efficiently separate electron-hole pairs. As a consequence, the photovoltaic performance of $\mathrm{SnO}_{2} / \mathrm{CdO} / \mathrm{Si}$ double-layer solar cell (DLSC) is highly improved compared to the controlled $\mathrm{Si}$ solar cell, $\mathrm{CdO} / \mathrm{Si}$ and $\mathrm{SnO}_{2} / \mathrm{Si}$ single-layer solar cells (SLSCs). Via alignment engineering, the $\mathrm{SnO}_{2} / \mathrm{CdO} / \mathrm{Si}$ DLSC produces a short circuit photocurrent $\left(J_{s c}\right)$ of $38.20 \mathrm{~mA} / \mathrm{cm}^{2}$, an open circuit photovoltage $\left(V_{o c}\right)$ of $0.575 \mathrm{~V}$ and a fill factor $(\mathrm{FF})$ of $68.7 \%$, a conversion efficiency $(\eta)$ of $15.09 \%$ under AM1.5 illumination.

Keywords: silicon solar cells; semiconductors; electron-hole pairs

\section{Introduction}

Solar cells have been developing for more than five decades. From the very first generation solar cell to the latest one, the conversion efficiency of the solar cell itself has been largely improved. The update conversion efficiency of GaInP/GaAs solar cells have broken 40\% [1-4]. However, these high efficiency solar cells still have many disadvantages, such as stability issues and high cost, so that they can hardly be put into large-scale production. At this point, with the combination of high purity, natural abundance, a matching insulator, and maturity of production [5,6], crystalline silicon (c-Si) solar cells show their unique advantageous properties. However, there still are several defects of c-Si solar cells, such as optical loss, recombination, and thermal or quantum losses. Among them, optical loss and recombination are deemed to be the two most vital factors. Many efforts have been made by researchers to solve these problems. Silicon nanowires [7-9], ZnO nanowires [10], and $\mathrm{CuO}$ nanoleaves [11] are some of those extraordinary attempts. The power conversion efficiency has been improved through light trapping enhancement and photocarrier collection facilitation [12,13]. The $\mathrm{TiO}_{2}$ half-prolates light trapping schemes were designed to optimize photonic elements on top of unstructured planar absorber layers in the Si cells' front [14]. $\mathrm{An} \mathrm{Al}_{2} \mathrm{O}_{3}$ nanopatterned point structure was used to achieve the rear passivation [15]. It has opened up new opportunities to achieve higher energy conversion efficiency at lower fabrication costs.

Although many textured structures have been made to enhance absorptance of c-Si solar cells, c-Si is still an indirect band-gap semiconductor with a bandgap of $1.12 \mathrm{eV}$, which is able to utilize only a small fraction of the solar spectrum. Currently, the tandem solar cell is considered to be one of the 
most promising approaches of the third generation solar cells to solve this problem. It is fabricated with two or more sub-cells which are tandemed according to their bandgaps [16]. The overall open circuit voltage $\left(V_{o c}\right)$ is the sum of those from all individual sub-cells, while the current is the same as that in a single sub-cell once their currents are matched [17-19]. As a result, tandem solar cell have broadened absorption spectrum effectively, so that they can tackle absorption and thermalization losses simultaneously by absorbing the higher energy photons, improving the conversion performance.

By using the concept of tandem solar cells for reference, band-gap alignment engineering has been developed for various applications, such as quantum dot solar cells through band alignment engineering [20]. Here we applied $\mathrm{CdO}$ and $\mathrm{SnO}_{2}$ semiconductors to c-Si solar cells. $\mathrm{CdO}$ is one of the transparent conducting oxides (TCOs) that has moderate band-gap and high electrical conductivity. Because of high mobility, $\mathrm{CdO}$ is also believed to have large potential for the use in active electronic devices [21,22]. $\mathrm{SnO}_{2}$ has wide bandgap of 3.5-4.0 eV and terrific electronic conductivity. It has a great prospect in solar cells. $\mathrm{SnO}_{2}$ nanostructures were used as the buffer layer of $\mathrm{Sb}_{2} \mathrm{Se}_{3}$ solar cell [23]. In our research, we have tried to synthesize different nano-structured films of $\mathrm{CdO}$ and $\mathrm{SnO}_{2}$ semiconductors on the surface of c-Si substrate, respectively. To comparatively investigate the electrical properties and the photovoltaic performance, $\mathrm{CdO} / \mathrm{Si}$ single-layer solar cell (SLSC), $\mathrm{SnO}_{2} / \mathrm{Si}$ SLSC, and $\mathrm{SnO}_{2} / \mathrm{CdO} / \mathrm{Si}$ double-layer solar cell (DLSC) were prepared. The controlled Si solar cell without any deposition was also prepared as a reference. The comparison of the controlled cell, two SLSCs, and $\mathrm{SnO}_{2} / \mathrm{CdO} / \mathrm{Si}$ DLSC demonstrates the impact of different layers with different bandgaps on the absorption region and the charge-transfer efficiency. As a result, the short-circuit current $\left(J_{s c}\right)$ and the open circuit voltage were improved, leading to the enhancement of power conversion efficiency (PCE). $\mathrm{SnO}_{2} / \mathrm{CdO} / \mathrm{Si}$ DLSC offers broad-band light harvesting and super high minority carrier lifetime. We believe that this cost effective technology can be easily applied in the industrial scale production of $\mathrm{Si}$ solar cells.

\section{Materials and Methods}

\subsection{Materials and Methods}

Slices $\left(3.0 \times 3.0 \mathrm{~cm}^{2}\right)$ of c-Si wafers without $\mathrm{Si}_{3} \mathrm{~N}_{4}$ antireflection layer were applied in this work. The thickness of wafers is $\sim 200 \mu \mathrm{m}$ with a bulk $p$ - $n$ junction. Before growing any film on the surface of Si wafer, it was cleaned by rinsing with double distilled water and ethanol to eliminate any impurities. Firstly, two depositing solutions were prepared as solution A and B. Solution A is $\mathrm{Cd}\left(\mathrm{CH}_{3} \mathrm{COO}\right)_{2}$ solution with the concentration of $0.05 \mathrm{M}$. In solution B, the concentration of $\mathrm{SnCl}_{4}$ is $0.01 \mathrm{M}$, and the 1:1 ethanol:water mixture is as solvent to prohibit hydrolysis. In order to grow $\mathrm{CdO}$ layer on the surface of Si wafers, the dried Si wafer was immersed in solution A for 2 min and was dried again in a drying oven at $80^{\circ} \mathrm{C}$. This procedure was repeated for over four times to ensure the $\mathrm{CdO}$ seeds were fully distributed on the silicon's surface. The deposited $\mathrm{Si}$ wafer was thermal treated at $500{ }^{\circ} \mathrm{C}$ for $3 \mathrm{~min}$, then the $\mathrm{CdO} / \mathrm{Si}$ was completed. $\mathrm{SnO}_{2} / \mathrm{Si}$ was synthesized through a spin-coating method. In this step, $0.05 \mathrm{~mL}$ of $0.01 \mathrm{M}$ Stannic chloride aqueous ethanol solution were dropped onto Si surface under the speed of $1500 \mathrm{rpm}$ for $40 \mathrm{~s}$, and this operation was conducted five times to ensure the Sn-precursor fully covered on the substrate. The deposited $\mathrm{Si}$ wafer was treated under $900{ }^{\circ} \mathrm{C}$ in muffle furnace for $5 \mathrm{~min}$ to form $\mathrm{SnO}_{2}$ film. Combining the above two procedures, $\mathrm{SnO}_{2} / \mathrm{CdO} / \mathrm{Si}$ was prepared. $\mathrm{SnO}_{2}$ was deposited on the surface of as-synthesized $\mathrm{CdO} / \mathrm{Si}$ composited cell and anneal at $900{ }^{\circ} \mathrm{C}$ for $5 \mathrm{~min}$. For electrochemical analysis, two electrodes were made on the above three deposited Si wafers. Ag grids were then screen-printed on front side, followed by rapid thermal annealing. Chemical vapor deposition (CVD) was employed to deposit $\mathrm{Al}$ on the reverse side of the c-Si substrates.

\subsection{Characterization}

Field emission scanning electron microscopy (FESEM HitachiS-4800, Hitachi High-Technologies GLOBAL, Tokyo, Japan) was used to evaluate the morphology and contents of the layers. 
The absorption spectra were measured on a Cary500 UV-vis-NIR spectrophotometer (Hitachi High-Technologies GLOBAL, Tokyo, Japan) using $\mathrm{BaSO}_{4}$ as a reference. The minority carrier lifetime of the samples was measured using the Si wafer life-time SEMILAB WT-2000 PVN (SEMILAB, Budapest, Hungary). The current density-voltage $(J-V)$ characteristics of the solar cells were measured using a Zennium electrochemical workstation (Zahner elektrik GmbH \& Co.KG, Thüringer Str. 1296317 Kronach, Germany) under $100 \mathrm{~mW} \mathrm{~cm}^{-2}$ calibration which is performed using a Class A AM 1.5 G spectral distributed Sun 2000 Solar Simulator (Abet Technologies, Inc., Milford, CT, USA). The external quantum efficiency were conducted by using a QTest Station (CROWNTECH, Inc., Indianapolis, IN, USA). The impedance measurements were performed on an external potentiostat (XPOT) of an electrochemical Zennium workstation (Zahner elektrik GmbH \& Co.KG, Kronach, Germany) with a frequency ranging from $100 \mathrm{KHz}$ down to $0.1 \mathrm{~Hz}$ at forward bias potentials between 0 and $0.5 \mathrm{~V}$ (with a $5 \mathrm{mV}$ sinusoidal AC perturbation). The resulting impedance spectra were analyzed with ZSipWin software (v3.10, EChem Software, eDAQ Inc., Colorado Springs, CO, USA).

\section{Results and Discussion}

Figure 1 shows the surface morphologies of both $\mathrm{CdO}$ and $\mathrm{SnO}_{2}$ films deposited on the surface of polycrystalline silicon with $p$ - $n$ junction, respectively. As shown in Figure $1 \mathrm{a}, \mathrm{CdO}$ film was characterized by scanning electron microscope (SEM). The cross-sectional view indicates that the thickness of the film is about $32 \mathrm{~nm}$, and its surface is smooth with comparing top view pictures. While in Figure 1b, $\mathrm{SnO}_{2}$ film shows a different surface morphology with many hollows, and it is approximately $41 \mathrm{~nm}$ in thickness, slightly thicker than $\mathrm{CdO}$ film. With those pictures we can find that both two films have a firm contact with Si substrates, which is beneficial in reducing contact resistance and electron transfer. Figure $1 \mathrm{c}$ demonstrates the schematic of $\mathrm{SnO}_{2} / \mathrm{CdO} / \mathrm{Si}$ DLSC. With spin-coating method and annealing treatments, $\mathrm{CdO}$ layer and $\mathrm{SnO}_{2}$ layer were grown on $\mathrm{Si}$ substrate in sequence. On one hand, the top layer with a rough surface of $\mathrm{SnO}_{2}$ can efficiently increase light trapping. On the other hand, two layers are capable of utilizing utilize different regions of incident light.
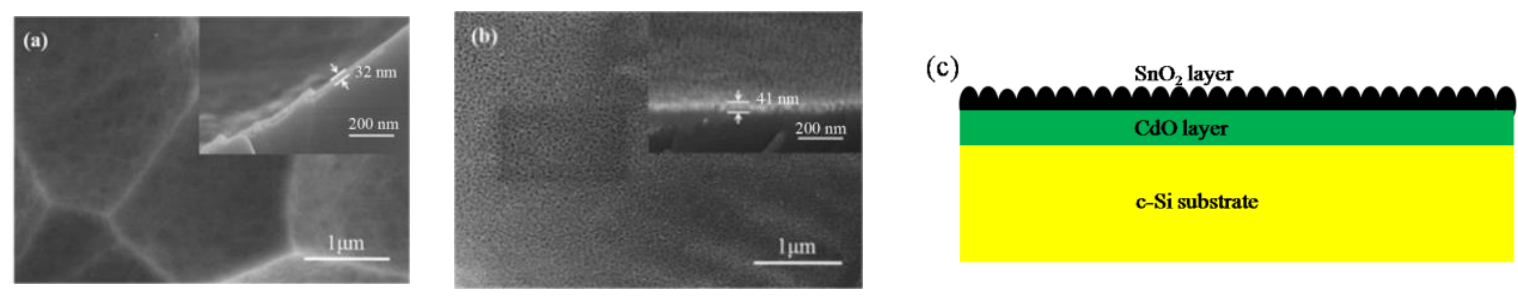

Figure 1. Cross-section and top views of SEM morphologies of (a) $\mathrm{CdO}$; and (b) $\mathrm{SnO}_{2}$ films growing on polycrystalline silicon substrates, respectively, and the cross-sectional views are the inset; (c) schematic of $\mathrm{SnO}_{2} / \mathrm{CdO} / \mathrm{Si}$ DLSC.

FESEM energy dispersive spectrometry (EDS) element mapping of composited $\mathrm{SnO}_{2} / \mathrm{CdO} / \mathrm{Si}$ DLSC was conducted to take deep research on the structure of layer-by-layer. Figure 2a is the scanning region of $\mathrm{SnO}_{2} / \mathrm{CdO} / \mathrm{Si}$ composited wafer, while Figure $2 \mathrm{~b}$ is the element mapping of all detected elements. Figure $2 \mathrm{c}-\mathrm{f}$ refer to element $\mathrm{Si}, \mathrm{O}, \mathrm{Sn}$, and $\mathrm{Cd}$, respectively. From Figure $2 \mathrm{c}-\mathrm{f}$, we can find that the elements are well-distributed on the surface of c-Si substrate which indicates that the layer-by-layer structure was greatly formed by spin-coating and annealing procedures. 

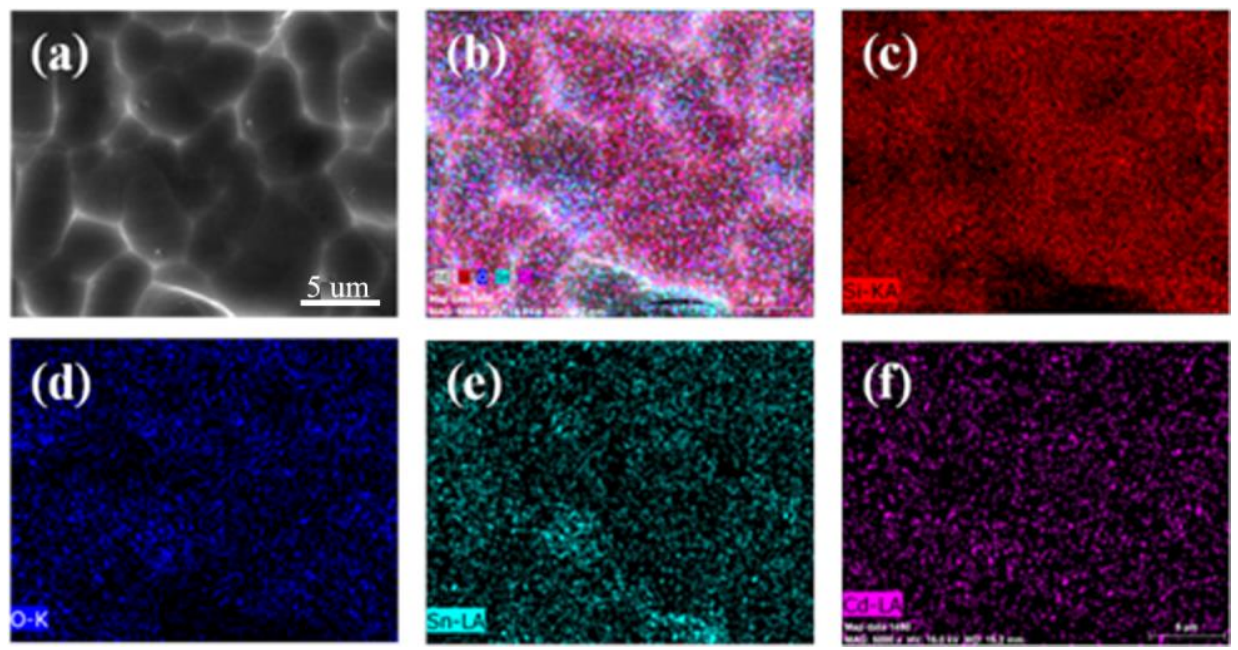

Figure 2. (a) FESEM of the composited $\mathrm{SnO}_{2} / \mathrm{CdO} / \mathrm{Si} \mathrm{DLSC}$, (b) the element mapping of all detected elements, (c) $\mathrm{Si}$, (d) $\mathrm{O}$, (e) $\mathrm{Sn}$, and (f) Cd elements.

According to different morphologies above, different absorption spectra were measured by UV-vis-IR. In Figure 3, Si substrate with CdO layer shows almost the same absorption property as $\mathrm{Si}$ wafer except the slight improvement between 300 and $450 \mathrm{~nm}$. As to $\mathrm{SnO}_{2}$ layer, the absorption value from 300 to $1100 \mathrm{~nm}$ is improved by about $16 \%$. This phenomenon results from their different surface structures. Because of the hollows on the surface, the film can cause optical resonance and multiple scattering of the incident light, which can trap incident light and enhance absorptance effectively [24-26]. In addition, due to its wide bandgap, $\mathrm{SnO}_{2}$ film is capable to utilize much more light compared to c-Si wafer. In addition, the $\mathrm{SnO}_{2} / \mathrm{CdO}$ film coatings have an antireflection effect on the solar irradiation. The $\mathrm{SnO}_{2} / \mathrm{CdO}$ coatings can reduce the reflections from the $\mathrm{Si}$ wafer surfaces and then increase the absorption. Therefore, the $\mathrm{SnO}_{2} / \mathrm{CdO}$ DLSC has the best absorption in the range of $300-1000 \mathrm{~nm}$.

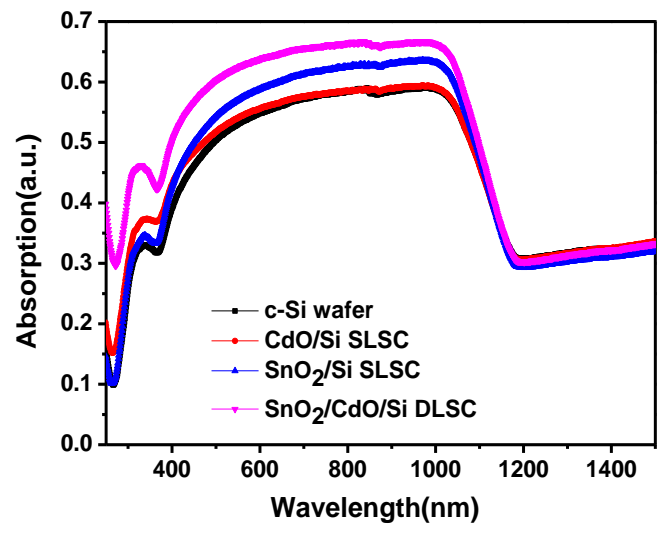

Figure 3. UV-vis-IR absorption spectra for $\mathrm{Si}$ wafer, $\mathrm{CdO} / \mathrm{Si}, \mathrm{SnO}_{2} / \mathrm{Si} \mathrm{SLSCs}$, and $\mathrm{SnO}_{2} / \mathrm{CdO} / \mathrm{Si}$ DLSC.

To further investigate photovoltaic properties of composited solar cells, external quantum efficiency (EQE) spectra and $J-V$ curves were conducted under the standard AM 1.5 G conditions. Figure 4a shows that a broad value of $70-80 \%$ in the spectrum of pristine Si solar cell is observed from 500-900 nm which corresponds to the wavelength range of Si light absorption. In contrast, the spectrum of $\mathrm{SnO}_{2} / \mathrm{Si}$ SLSC exhibits a large increase in EQE spectrum for the wavelength between 300-550 nm, while CdO/Si SLSC is a little lower than that of $\mathrm{SnO}_{2} / \mathrm{Si}$ SLSC. On one hand, as two semiconductors with wide bandgaps $\left(\mathrm{Eg}_{\mathrm{CdO}}=2.4 \mathrm{eV}, \mathrm{Eg}_{\mathrm{SnO} 2}=3.5 \mathrm{eV}\right), \mathrm{CdO}$ and $\mathrm{SnO}_{2}$ can effectively 
absorb spectrum wavelengths between 300 and $600 \mathrm{~nm}$. That means the $\mathrm{CdO}$ layer and $\mathrm{SnO}_{2}$ layer are able to use incident light from 300 to $600 \mathrm{~nm}$ and generate more high energy carriers. On the other hand, according to UV-vis-IR absorption spectra, both CdO/Si SLSC and $\mathrm{SnO}_{2} / \mathrm{Si}$ SLSC have been enhanced between 300 and $600 \mathrm{~nm}$. As we know, if solar cells absorb more incident light, more photons can be utilized to generate carriers, so the improvement of EQE can be also attributed to the enhancement of absorption performance. Since the absorption in the range of 800-1000 nm is increased due to the antireflection effect and the hollow structure of $\mathrm{SnO}_{2}$ layer, the EQE in the range of $800-1000 \mathrm{~nm}$ is increased. Though the absorption in the range of $600-800 \mathrm{~nm}$ is also increased, the sensitivity of Si cell to the $600-800 \mathrm{~nm}$ irradiation is not as good as that to the $800-1000 \mathrm{~nm}$ irradiation. The EQE increase is not obvious in in the range of $600-800 \mathrm{~nm}$. Finally, the EQE performance of $\mathrm{SnO}_{2} / \mathrm{CdO} / \mathrm{Si}$ DLSC matches the theory we discussed above as well.

(a)

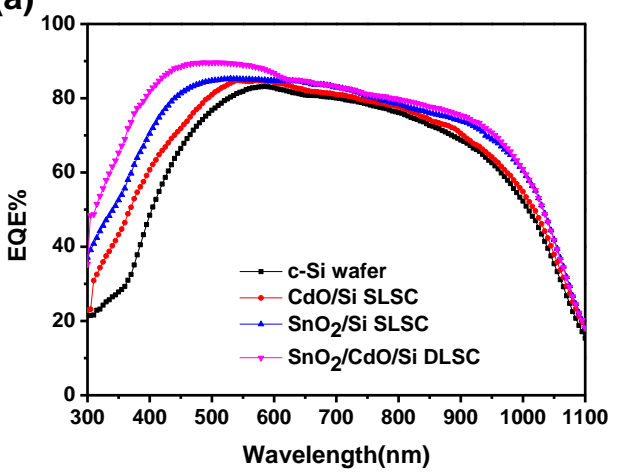

(b)

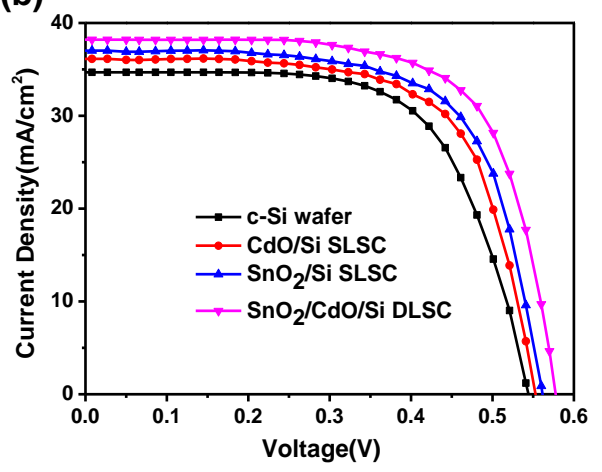

Figure 4. (a) External quantum efficiency (EQE) spectra and (b) $J$ - $V$ characteristics for blank c-Si solar cell, $\mathrm{CdO} / \mathrm{Si}, \mathrm{SnO}_{2} / \mathrm{Si} \mathrm{SLSC}$, and $\mathrm{SnO}_{2} / \mathrm{CdO} / \mathrm{Si}$ DLSC.

The detailed device performance is summarized in Table 1 and the $J-V$ characteristic curves are shown in Figure $4 \mathrm{~b}$. As a result, the PCE of CdO/Si SLSC reaches a value as high as $13.34 \%$, with $J_{s c}$ of $36.12 \mathrm{~mA} \mathrm{~cm}{ }^{-2}, V_{o c}$ of $0.556 \mathrm{~V}$ and FF of $66.42 \%$, while values of $\mathrm{SnO}_{2} / \mathrm{Si}$ SLSC are $13.96 \%$, $37.01 \mathrm{~mA} \mathrm{~cm}^{-2}, 66.76 \%$. Compared to pristine Si solar cell without any metal oxide film growing on the top, the $V_{o c}$ performance are improved by $2.6 \%$ and $4.2 \%$. Whereas as for current density, three as-synthesized solar cells all have various increases compared to the controlled Si solar cell. The short-circuit currents are mainly related with three factors as we concluded, and the first one is light absorption. The photoactive layer in the solar device absorbs sunlight, raising an electron from the ground state to a higher energy state and then generates an energy bearing electron-hole pair, called an excition [27]. As we know, c-Si is an indirect band-gap semi-conductor with a band-gap of $1.12 \mathrm{eV}$ and the perfect light spectra region for absorption of c-Si is approximately $700 \sim 1100 \mathrm{~nm}$ which is only a small part of the whole solar spectrum. In order to maximize $J_{s c}$, it is necessary to make full use of the solar spectrum. The more solar spectrum is utilized, the more photo-generated carriers are produced. However, a large part of these photo-generated carriers are wasted directly through recombination. It indicates that if electron-hole pairs can be efficiently separated before recombination, $J_{s c}$ value is supposed to be enhanced to a large extend. In addition, to ensure an efficient collection of charge carriers, carrier transporting layers are required to have high mobility as well as long diffusion lengths for electrons and holes [28-30], and the resistance is also a factor affecting current flowing. In our research, $J_{s c}$ of $\mathrm{CdO} / \mathrm{Si}$ and $\mathrm{SnO}_{2} / \mathrm{Si}$ solar cells are increased to $36.12 \mathrm{~mA} \mathrm{~cm}^{-2}$ and $37.01 \mathrm{~mA} \mathrm{~cm}^{-2}$. The increase can be ascribed to absorption enhancement as shown in Figure 3a and charge carrier lifetime increase as shown in Figure 5. 
Table 1. Photovoltaic performance parameters of blank c-Si solar cell and as-synthesized CdO/Si and $\mathrm{SnO}_{2} / \mathrm{Si} \mathrm{SLSC}$ and $\mathrm{SnO}_{2} / \mathrm{CdO} / \mathrm{Si}$ DLSC.

\begin{tabular}{cccccc}
\hline Solar Cell & $V_{\boldsymbol{o c}}(\mathbf{V})$ & $J_{\boldsymbol{s c}}\left(\mathbf{m A ~ c m}^{-\mathbf{2}}\right)$ & FF (\%) & $\boldsymbol{\eta}(\mathbf{\%})$ & $\Delta \boldsymbol{\eta}(\mathbf{\%})$ \\
\hline $\mathrm{c}-\mathrm{Si}$ & 0.542 & 34.68 & 65.33 & 12.28 & - \\
$\mathrm{CdO} / \mathrm{Si}$ & 0.556 & 36.12 & 66.42 & 13.34 & 8.6 \\
$\mathrm{SnO}_{2} / \mathrm{Si}$ & 0.565 & 37.01 & 66.76 & 13.96 & 13.6 \\
$\mathrm{SnO}_{2} / \mathrm{CdO} / \mathrm{Si}$ & 0.575 & 38.20 & 68.70 & 15.09 & 22.8 \\
\hline
\end{tabular}

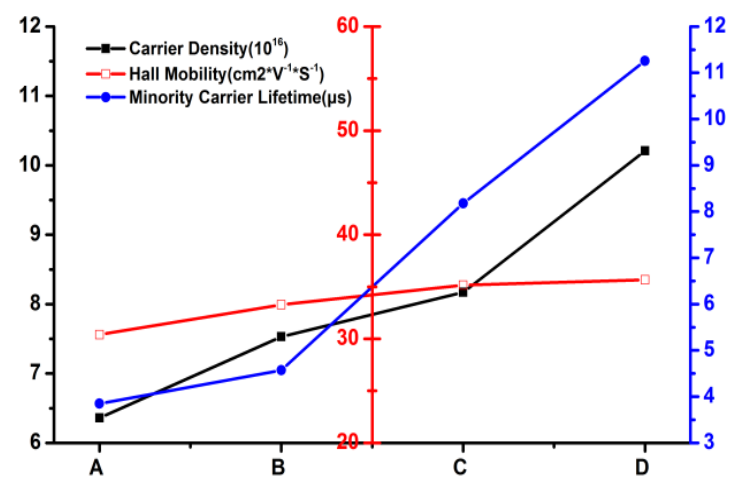

Figure 5. Carrier density, Hall mobility, and minority carrier lifetime properties of (A) c-Si solar cell, (B) $\mathrm{CdO} / \mathrm{Si} \mathrm{SLSC}$, (C) $\mathrm{SnO}_{2} / \mathrm{Si} \mathrm{SLSC}$, and (D) $\mathrm{SnO}_{2} / \mathrm{CdO} / \mathrm{Si}$ DLSC.

In Figure 5, we can also see that carrier density values of three kinds of as-synthesized solar cells are all enhanced. As we discussed above, because of good solar spectrum absorption property and band-gap alignment engineering, the composited solar cells are able to make better use of solar spectra and thus produce more photo-generated carriers. Carrier density is an important parameter to measure the utilized efficiency of absorbed photons. CdO owns a wider bandgap than c-Si, so short wavelength irradiation is fully used according to the results of UV-vis-IR absorption and EQE property shown in Figure 3. For the same reason, as bandgap of $\mathrm{SnO}_{2}$ is even wider, the EQE and UV-vis-IR results indicate the carrier density enhancement which is correspondent with that measured in Figure 5. Moreover, Hall mobility is highly related to electrical conductivity. The result in Figure 5 (red line) shows that the speed of carrier transport is not decayed but improved instead, due to the CdO layer and $\mathrm{SnO}_{2}$ layer deposited on top of c-Si substrates. This phenomenon demonstrates that $\mathrm{CdO}$ layer and $\mathrm{SnO}_{2}$ layer we have synthesized play a role as good electron transport layers. When $\mathrm{CdO}$ and $\mathrm{SnO}_{2}$ were made to grow on surface of c-Si substrates by a spin coating method, homogeneous films were produced through tuning spinning speed and coating time. After annealing at $500{ }^{\circ} \mathrm{C}$ and $900{ }^{\circ} \mathrm{C}$ respectively, firm Ohmic contact thin oxide films and c-Si substrates were formed, which is supposed to decrease the series resistance. A blue line is put to demonstrate the change of minority carrier lifetime. The result shows that, after being covered by different oxide layers, the lifetime of the minority carrier is highly increased. The effective carrier lifetime $\left(\tau_{\text {eff }}\right)$ is directly related to the bulk lifetime $\left(\tau_{\text {bulk }}\right)$ and the surface life time ( $\tau_{\text {surf }}$ ) and the $\tau_{\text {bulk }}$ dominates the $\tau_{\text {eff }}$ [31]. The increase in $J_{s c}$ and $V_{o c}$ partly resulted from improved minority carrier lifetime can be understood by the relations below [32]

$$
\begin{gathered}
V_{O C}=\frac{k t}{q} \ln \left(\frac{\Delta n\left(N_{D, A}+\Delta n\right)}{n_{i}{ }^{2}}\right) \\
J_{s c}=q G\left(L_{n}+L_{p}\right)
\end{gathered}
$$

where $k t / q$ is the thermal voltage, $N_{D, A}$ is the donor or acceptor concentration of the wafer, $\Delta n$ is the excess carrier concentration, $n_{i}$ is the intrinsic carrier concentration, $q$ is the magnitude of the electrical charge on the electron, $G$ is the generation rate, and $L_{n}$ and $L_{p}$ are electron and hole diffusion 
lengths, respectively. We can find that $V_{o c}$ and $J_{S C}$ strongly depend on excess carrier concentration and diffusion lengths which are directly proportional to the $\tau_{\text {eff }}$. That is to say, the increase of minority carrier lifetime gives rise to the enhancement of $J_{\mathcal{S C}}$ and $V_{o c}$, which in the end contribute to power conversion efficiency.

To further investigate the mechanism of charge-transfer and electron-hole separation, we here illustrate the schematic diagram representing charge-transfer and electron-hole separation process in Scheme 1. As shown in the diagram, the conduction band (CB) of $\mathrm{SnO}_{2}$ lies at a more negative potential than that of $\mathrm{CdO}$, while the valence band $(\mathrm{VB})$ of $\mathrm{CdO}$ is more negative than that of $\mathrm{SnO}_{2}$. Under solar irradiation, photo-generated electrons in the conduction band of $\mathrm{SnO}_{2}$ go to the conduction band of $\mathrm{CdO}$, and hole transfer occurs from the valence band of $\mathrm{CdO}$ to that of $\mathrm{SnO}_{2}$. At the same time, with a similar reason for c-Si substrate, electrons from conduction band of $\mathrm{CdO}$ transfer to that of c-Si, and holes transfer from valence band of $\mathrm{CdO}$ to that of $\mathrm{c}-\mathrm{Si}$. The simultaneous transfer of electrons and holes in $\mathrm{SnO}_{2} / \mathrm{CdO} / \mathrm{Si}$ system increase both the yield and the lifetime of charge carriers by separating the photo-induced electrons and reducing charge recombination in the electron-transfer process [33]. In our research, the results of minority carrier lifetime, carrier density, and short current density are able to perfectly support the schematic diagram we discussed above.

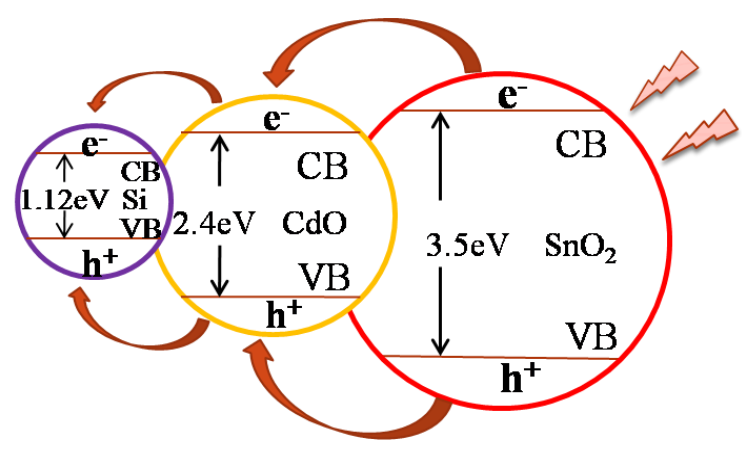

Scheme 1. Schematic diagram representing the charge-transfer and electron-hole separation process in $\mathrm{SnO}_{2} / \mathrm{CdO} / \mathrm{Si}$ DLSC.

X-ray photoelectron spectroscopy (XPS) was also conducted to study the compositions and chemical states of as-synthesized $\mathrm{SnO}_{2} / \mathrm{CdO} / \mathrm{Si}$ composited solar cell. Figure $6 \mathrm{a}, \mathrm{b}$ compare the XPS survey spectrum of $\mathrm{CdO} / \mathrm{Si}$ and $\mathrm{SnO}_{2} / \mathrm{CdO} / \mathrm{Si}$. In comparison to $\mathrm{CdO} / \mathrm{Si}$, the XPS survey spectrum of $\mathrm{SnO}_{2} / \mathrm{CdO} / \mathrm{Si}$ exhibits four additional $\mathrm{Sn}$ peaks, and two strongest peaks refer to $\mathrm{Sn} 3 \mathrm{~d}_{3 / 2}$ and $\mathrm{Sn}$ $3 d_{5 / 2}$. When focusing on $\mathrm{Cd} 3 \mathrm{~d}$, we can find that peaks of $\mathrm{Cd} 3 \mathrm{~d}$ in Figure $6 \mathrm{~b}$ are apparently much weaker than that in Figure 6a. Because of a $\sim 40 \mathrm{~nm}$ thickness $\mathrm{SnO}_{2}$ layer covered on top of CdO layer with spin-coating method, XPS signal of $\mathrm{Cd}$ was heavily blocked by $\mathrm{SnO}_{2}$ layer. The $\mathrm{Cd} 3 \mathrm{~d}$ core level spectra of $\mathrm{CdO} / \mathrm{Si}$ solar cell and $\mathrm{SnO}_{2} / \mathrm{CdO} / \mathrm{Si}$ solar cell are shown in Figure $6 \mathrm{c}$. For $\mathrm{CdO} / \mathrm{Si}$, peaks of $\mathrm{Cd} 3 \mathrm{~d}$ center at $405.42 \mathrm{eV}$ and $412.17 \mathrm{eV}$ which are consistent with the values reported for $\mathrm{Cd}^{2+}$, while peaks of $\mathrm{Cd} 3 \mathrm{~d}_{5 / 2}$ and $\mathrm{Cd} 3 \mathrm{~d}_{3 / 2}$ are located at $405.81 \mathrm{eV}$ and $412.57 \mathrm{eV}$ respectively for $\mathrm{SnO} / \mathrm{CdO} / \mathrm{Si}$ solar cell [34]. There is an approximate $0.4 \mathrm{eV}$ increase in binding energy of $\mathrm{Cd} 3 \mathrm{~d}$ between $\mathrm{CdO} / \mathrm{Si}$ and $\mathrm{SnO}_{2} / \mathrm{CdO} / \mathrm{Si}$, which illustrates that the extraction of nuclei and electrons becomes stronger. It is believed that $\mathrm{SnO}_{2}$ crystalline and $\mathrm{CdO}$ crystalline are affected by each other and formed a kind of hetero-structure. This new formation of structure gives a vital impact on carrier-transport between different layers and also leads to a drastic improvement in the photovoltaic performance of $\mathrm{SnO}_{2} / \mathrm{CdO} / \mathrm{Si}$ DLSC. 

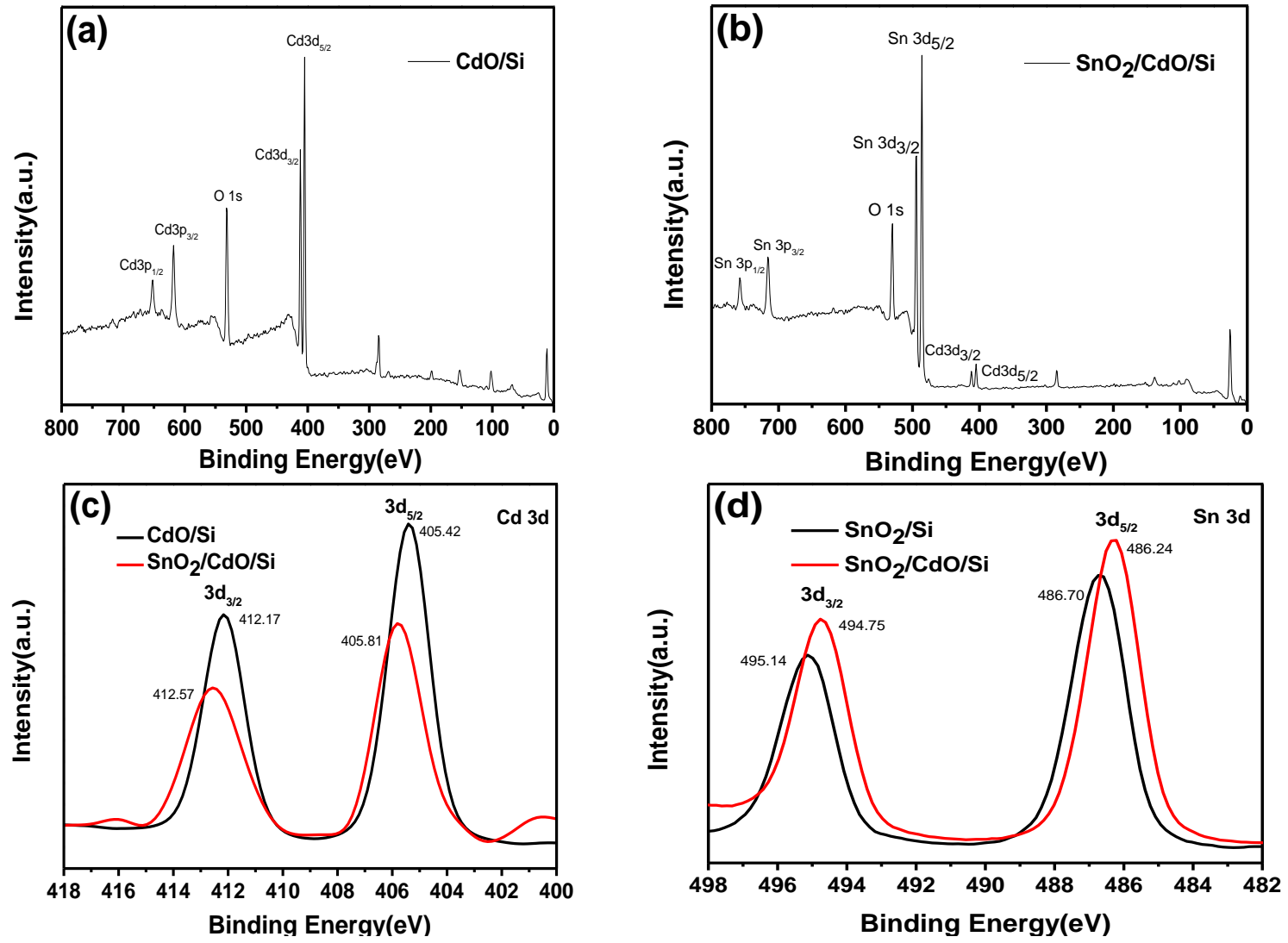

Figure 6. XPS survey spectra of (a) CdO/Si SLSC and (b) composited $\mathrm{SnO}_{2} / \mathrm{CdO} / \mathrm{Si}$ DLSC. Core level (c) Cd 3d, (d) Sn 3d XPS spectra.

\section{Conclusions}

In conclusion, we investigated the photovoltaic performance of crystalline silicon solar cells using different metal oxide layers by band-gap alignment engineering that act as wavelength broadening layers for optical absorption and effective carrier separation and transport layers. The photovoltaic performance of as-synthesied $\mathrm{SnO}_{2} / \mathrm{Si} \mathrm{SLSC}, \mathrm{CdO} / \mathrm{Si} \mathrm{SLSC}$, and $\mathrm{SnO}_{2} / \mathrm{CdO} / \mathrm{Si}$ DLSC were considerably improved in comparison with original c-Si solar cells. The highest PCE value was $15.09 \%$ for $\mathrm{SnO}_{2} / \mathrm{CdO} / \mathrm{Si}$ DLSC as measured while $12.28 \%$ for original c-Si solar cells. In addition, the recombination of photogenerated carriers was greatly restrained, resulting in a high minority carrier lifetime value. It is believed that by using band-gap alignment engineering, crystalline silicon solar cells still have deeper potential for further exploration.

Author Contributions: L.Z. performed the experiments, analyzed the data, and wrote the paper; L.X. analyzed the data; H.Y. performed the experiments, analyzed the data, and revised the paper; J.L. conceived and designed the experiments and revised the paper; X.Y. conceived and designed the experiments.

Funding: This study is supported by the Key Project of Excellent Youth Talent Support Plan of Anhui Province (gxyqZD2016540), Natural Science Foundation of Education Department of Anhui Province (KJ2018A0834), Natural Science Foundation of Education Department of Anhui Province (KJ2017ZD49), Talent Project of the College (ZD2017004) and PCSIRT (IRT_16R49).

Conflicts of Interest: The authors declare no conflicts of interest.

\section{References}

1. Cotal, H.; Fetzer, C.; Boisvert, J.; Kinsey, G.; King, R.; Hebert, P.; Yoon, H.; Karam, N. III-V multijunction solar cells for concentrating photovoltaics. Energy Environ. Sci. 2009, 2, 174-192. [CrossRef] 
2. Bertness, K.A.; Kurtz, S.R.; Friedman, D.J.; Kibbler, A.E.; Kramer, C.; Olson, J.M. 29.5\%-efficient GalnP/GaAs tandem solar cells. Appl. Phys. Lett. 1994, 65, 989-991. [CrossRef]

3. Yamaguchi, M.; Takamoto, T.; Araki, K.; Ekins-Daukes, N. Multi-junction III-V solar cells: Current status and future potential. Sol. Energy 2005, 79, 78-85. [CrossRef]

4. Siddiki, M.K.; Li, J.; Galipeau, D.; Qiao, Q. A review of polymer multijunction solar cells. Energy Environ. Sci. 2010, 3, 867-883. [CrossRef]

5. Priolo, F.; Gregorkiewicz, T.; Galli, M.; Krauss, T.F. Silicon nanostructures for photonics and photovoltaics. Nat. Nanotechol. 2014, 9, 19-32. [CrossRef] [PubMed]

6. Tisdale, W.A.; Williams, K.J.; Timp, B.A.; Norris, D.J.; Aydil, E.S.; Zhu, X.Y. Hot-electron transfer from semiconductor nanocrystals. Science 2010, 328, 1543-1547. [CrossRef] [PubMed]

7. Wang, X.; Peng, K.Q.; Pan, X.J.; Chen, X.; Yang, Y.; Li, L.; Meng, X.M.; Zhang, W.J.; Lee, S.T. High-performance silicon nanowire array photoelectrochemical solar cells through surface passivation and modification. Angew. Chem. Int. Ed. 2011, 50, 9861-9865. [CrossRef] [PubMed]

8. Garnett, E.; Yang, P. Light trapping in silicon nanowire solar cells. Nano Lett. 2010, 10, 1082-1087. [CrossRef] [PubMed]

9. Peng, K.Q.; Lee, S.T. Silicon nanowires for photovoltaic solar energy conversion. Adv. Mater. 2011, 23, 198-215. [CrossRef] [PubMed]

10. Pudasaini, P.R.; Ruiz-Zepeda, F.; Sharma, M.; Elam, D.; Ponce, A.; Ayon, A.A. High efficiency hybrid silicon nanopillar-polymer solar cells. ACS Appl. Mater. Interfaces 2013, 5, 9620-9627. [CrossRef] [PubMed]

11. Xia, Y.S.; Pu, X.X.; Liu, J.; Liang, J.; Liu, P.J.; Li, X.Q.; Yu, X.B. CuO nanoleaves enhance the c-Si solar cell efficiency. J. Mater. Chem. A 2014, 2, 6796-6800. [CrossRef]

12. Ferry, V.E.; Verschuuren, M.A.; Lare, M.C.; Schropp, R.E.I.; Atwater, H.A.; Polman, A. Optimized spatial correlations for broadband light trapping nanopatterns in high efficiency ultrathin film a-Si:H solar cells. Nano Lett. 2011, 11, 4239-4245. [CrossRef] [PubMed]

13. Wang, K.X.; Yu, Z.; Liu, V.; Cui, Y.; Fan, S. Absorption enhancement in ultrathin crystalline silicon solar cells with ction and light-trapping nanocone gratings. Nano Lett. 2012, 12, 1616-1619. [CrossRef] [PubMed]

14. Mendes, M.J.; Araújo, A.; Vicente, A.; Águas, H.; Ferreira, I.; Fortunato, E.; Martins, R. Design of optimized wave-optical spheroidal nanostructures for photonic-enhanced solar cells. Nano Energy 2016, 26, 286-296. [CrossRef]

15. Pedro, M.P.S.; Bart, V.; Rodrigo, R.A.; Jennifer, P.T.; José, M.V.C.; Manuel, J.M.; Sirazul, H.; Jerome, B.; Hugo, Á.; Elvira, F.; et al. Passivation of interfaces in thin film solar cells: Understanding the effects of a nanostructured rear point contact layer. Adv. Mater. Interface 2018, 5, 1701101-1701109. [CrossRef]

16. Eisler, C.N.; Abrams, Z.R.; Sheldon, M.T.; Zhang, X.; Atwater, H.A. Multijunction solar cell efficiencies: Effect of spectral window, optical environment and radiative coupling. Energy Environ. Sci. 2014, 7, 3600-3605. [CrossRef]

17. Ameri, T.; Dennler, G.; Lungenschmied, C.; Brabec, C.J. Organic tandem solar cells: A review. Energy Environ. Sci. 2009, 2, 347-363. [CrossRef]

18. Dou, L.; You, J.; Yang, J.; Chen, C.-C.; He, Y.; Murase, S.; Moriarty, T.; Emery, K.; Li, G.; Yang, Y. Tandem polymer solar cells featuring a spectrally matched low-bandgap polymer. Nat. Photon. 2012, 6, 180-185. [CrossRef]

19. Gilot, J.; Wienk, M.M.; Janssen René, A.J. Double and triple junction polymer solar cells processed from solution. Appl. Phys. Lett. 2007, 90, 143512. [CrossRef]

20. Dennler, G.; Scharber, M.C.; Brabec, C.J. Polymer-fullerene bulk-heterojunction solar cells. Adv. Mater. 2009, 21, 1323-1338. [CrossRef]

21. Chuang, C.-H.M.; Brown, P.R.; Buloviæ, V.; Bawendi, M.G. Improved performance and stability in quantum dot solar cells through band alignment engineering. Nat. Mater. 2014, 13, 796-801. [CrossRef] [PubMed]

22. Saha, B.; Thapa, R.; Chattopadhyay, K.K. Bandgap widening in highly conducting CdO thin film by Ti incorporation through radio frequency magnetron sputtering technique. Solid State Commun. 2008, 145, 33-37. [CrossRef]

23. Guo, X.H.; Guo, H.F.; Ma, Z.J.; Ma, C.H.; Ding, J.N.; Yuan, N.Y. Low-temperature deposited $\mathrm{SnO}_{2}$ used as the buffer layer of $\mathrm{Sb}_{2} \mathrm{Se}_{3}$ solar cell. Mater. Lett. 2018, 222, 142-145. [CrossRef]

24. Wang, H.P.; Lien, D.H.; Tsai, M.L.; Lin, C.A.; Chang, H.C.; Lai, K.Y.; He, J.H. Photon management in nanostructured solar cells. J. Mater. Chem. C 2014, 2, 3144-3171. [CrossRef] 
25. Liu, X.G.; Coxon, P.R.; Peters, M.; Hoex, B.; Cole, J.M.; Fray, D.J. Black silicon: Fabrication methods, properties and solar energy applications. Energy Environ. Sci. 2014, 7, 3223-3263. [CrossRef]

26. Chen, G.Y.; Seo, J.W.; Yang, C.H.; Prasad, P.N. Nanochemistry and nanomaterials for photovoltaics. Chem. Soc. Rev. 2013, 42, 8304-8338. [CrossRef] [PubMed]

27. Zhuang, X.J.; Ning, C.Z.; Pan, A. Composition and bandgap-graded semiconductor alloy nanowires. Adv. Mater. 2012, 24, 13-33. [CrossRef] [PubMed]

28. Xie, C.; Zhang, X.; Ruan, K.; Shao, Z.; Dhaliwal, S.S.; Wang, L.; Zhang, Q.; Zhang, X.; Jie, J. High-efficiency, air stable graphene/Si micro-hole array Schottky junction solar cells. J. Mater. Chem. A 2013, 1, 15348-15354. [CrossRef]

29. Baek, S.H.; Kim, S.-B.; Shin, J.K.; Kim, J.H. Preparation of hybrid silicon wire and planar solar cells having $\mathrm{ZnO}$ antireflection coating by all-solution processes. Sol. Energy Mater. Sol. Cells 2012, 96, 251-256. [CrossRef]

30. Polman, A.; Atwater, H.A. Photonic design principles for ultrahigh-efficiency photovoltaics. Nat. Mater. 2012, 11, 174-177. [CrossRef] [PubMed]

31. Sinton, R.A.; Cuevas, A. Contactless determination of current-voltage characteristics and minority-carrier lifetimes in semiconductors from quasi-steady-state photoconductance data. Appl. Phys. Lett. 1996, 69, 2510-2512. [CrossRef]

32. Wang, H.P.; Lin, T.Y.; Tsai, M.L.; Tu, W.C.; Huang, M.Y.; Liu, C.W.; Chueh, Y.L.; He, J.H. Toward efficient and omnidirectional n-type Si solar cells: Concurrent improvement in optical and electrical characteristics by employing microscale hierarchical structures. ACS Nano 2014, 8, 2959-2969. [CrossRef] [PubMed]

33. Yang, W.L.; Liu, Y.; Hu, Y.; Zhou, M.J.; Qian, H.S. Microwave-assisted synthesis of porous CdO-CdS core-shell nanoboxes with enhanced visible-light-driven photocatalytic reduction of $\mathrm{Cr}(\mathrm{VI})$. J. Mater. Chem. 2012, 22, 13895-13898. [CrossRef]

34. Li, W.; Li, M.Y.; Xie, S.L.; Zhai, T.; Yu, M.H.; Liang, C.L.; Ouyang, X.W.; Lu, X.H.; Li, H.H.; Tong, Y.X. Improving the photoelectrochemical and photocatalytic performance of $\mathrm{CdO}$ nanorods with $\mathrm{CdS}$ decoration. Cryst. Eng. Comm. 2013, 15, 4212-4216. [CrossRef]

(C) 2018 by the authors. Licensee MDPI, Basel, Switzerland. This article is an open access article distributed under the terms and conditions of the Creative Commons Attribution (CC BY) license (http:/ / creativecommons.org/licenses/by/4.0/). 